\title{
The Art Reference Library
}

\begin{abstract}
The author describes some of the unique collections in an art reference library. He discusses collections of photographs and slides and points out the importance of monographs on artists, catalogues raisonné, exhibition and permanent collection catalogs, and art sales catalogs. The selection of art periodicals and museum bulletins is stressed along with the importance of primary source material including treatises on art, guide books, and writings about artists by their contemporaries.
\end{abstract}

A $_{\text {art Library is made unique in part }}$ by its visual collections. Foremost among these is the photograph collection which records in one place works of art brought together from all over the world. The Witt library of the Courtauld Institute in London has stated as its goal the incredible and highly creditable wish to obtain a photograph of every work of art of importance in the Western World. No doubt this is an impossible task, but the goal is a sound one. In America no art reference library has undertaken the task of collecting visual materials with such vision. Even the Frick art reference library, which we look to as being highly useful, has not faced the problem in a really serious way. If we take one artist alone, Ingres, there are approximately six boxes of reproductions of his works -many of them clippings from wellknown monographs-in the Frick.

The Witt library has seventeen boxes of the same general type of this artist's works, with some one hundred photographs per box, or approximately seventeen hundred photographs and clippings

Mr. Cummings is Curator of European Art at the Detroit Institute of Arts and Adjunct Professor of Art History at Wayne State University. This paper was read to the Art Subsection of the Subject Specialists Section of ACRL at the Detroit Conference. of the works of Ingres. No doubt this is one of the greatest single depositories of visual material on Ingres in the world and approximately three times as much as is to be found in one of our great American photograph collections.

One of our most serious lacks is a photographic archive of national importance, an archive holding primarily photographs of works of art which could be borrowed or copied at minimum expense, and forwarded to any part of the country on request. The importance of a superior photograph collection to individual art reference libraries cannot be overstressed.

With regard to filing and storing photographs, a file card for each is not absolutely necessary if the photographic archive is an "open stack" arrangement where students and scholars may use it freely. The photographs serve as their own filing system. However, in a more sophisticated situation like that of the Frick art reference library, a card may be used for each photograph with separate indexes for subjects, collections, etc. Traditionally, photographs are stored in cardboard filing boxes. These are often inadequate, clumsy, and space-consuming. Filing cabinets would be much more efficient in most cases.

There are many sources for purchasing 
photographs of works of art. To mention only two or three, the Witt library in London sells photographic prints of most things in its collection at less than fifty cents each. Currently they are circulating for purchase a series of works of art in English country houses to approximately five American art reference libraries. One can subscribe to Gernsheim's photographs of drawings in European museums, which is fairly expensive, and photographs can now be purchased from the Index of Christian Art at Princeton. Photographs are necessary for research in preparing exhibitions, in purchasing works of art, and in researching the existing collection of the museum. Works of art themselves are difficult to transport, but photographs which give an immediate, detailed impression of the original are highly useful. The photograph collection can become a major part of an art reference library, as has occurred in the Frick library, where there are a number of useful files, including an iconographic one.

A secondary visual file within the art reference library may be a slide collection. Where the library is also a source of teaching materials, this may be a necessary province of the art librarian. In selecting slides a special talent for visual objects comes into play. Accuracy and harmony of color in the slide are particularly important if these are to be used for teaching purposes. The art librarian will have to learn, often without even seeing the original paintings, whether the colors in the transparency seem accurate for the period which it represents.

Other kinds of visual files, such as those for posters and clippings, may be maintained in an art reference library. However, these are not as important on the whole as the photograph collection. It should always be kept in mind that this sort of visual ephemera is effective only insofar as it is carefully and sys- tematically filed and indexed. Only when it is easily and readily available is material of this kind significant for research; otherwise it is relatively useless.

Although visual reference materials are basic to an art reference library and in a sense make it unique, these visual materials are found in a more important form in bound volumes of various kinds. The meat and potatoes of the art reference library are the monographs and catalogues raisonné on individual artists and periods. These range from softbound, multivolume French publications to elaborate portfolio-size facsimiles of master drawings produced in Italy, often without indexes or tables of contents of any kind.

A second category is to a degree unique to the art reference library. These are catalogs of temporary exhibitions and of permanent collections. These elusive yet quintessential ephemera are basic to the art reference library. Monographs make this kind of library a source of information; catalogs of collections including the individual work of art, its provenance, its physical make-up, its attributions to known artists, and its relationship to other works of art make the library a tool for research. Without these the art reference library is like a general library with a special artistic slant; with these it becomes a unique kind of research tool.

These exhibition catalogs, important though they be, are nevertheless an exhausting and continuous source of pain and frustration. One can never keep up with them. They are constantly being published; generally, no checklists exist; they are not standard works handled by publishers. They can often be purchased only at museums and then easily only during the few short weeks of the exhibition. Moreover, they vary greatly in importance. They may be simple lists, or they may be elaborate and highly detailed discussions by the best authorities 
in the field. Only recently has it been possible to subscribe to a list of exhibition catalogs prepared by World Wide Exhibition Catalogues, which has very good coverage. Nevertheless, they might miss that highly useful yet small and insignificant-looking catalog produced in East Anglia or by the municipal museum of Varallo, the most important work to date on the one artist born in the particular town.

Dealers' catalogs are especially difficult to keep up with. Often they do not have a great deal of information, yet they frequently reproduce objects that can be found in no other place. One can only keep track of these catalogs by following the advertisements in the bewildering number of art periodicals and requesting a copy of the catalog from the dealer at the time it appears, before the inevitably limited editions are dispersed.

Keeping up with these catalogs of temporary exhibitions from dealers and from museums is an absolutely essential part of an art librarian's "homework." It can only be done thoroughly by going through every periodical regularly-not just looking, but reading-to see if in the review of London exhibitions, for example, there is mention of an exhibition which would normally have a catalog, and writing at once to see if it is available. Often smaller catalogs are free.

Some may say, "These are too much trouble. We don't have time to bind and make cards for these useless pamphlets." The fact is that the more cataloging that can be done, the more useful the collection is. When temporary exhibition catalogs are at all specialized, they should be cataloged. This kind of ephemera may seem worthless, but to the art historian one completely obscure and minor catalog of twenty or thirty years ago with a reproduction of a painting now destroyed may be the key which solves an entire series of problems. The rule of thumb in this respect is that monographs allow for instruction, they disseminate information. Catalogs allow for research, they are the penetrating tentacles of our knowledge which allow for new discoveries in the field. It is on these that the knowledge which makes monographs is built.

The basic nucleus of temporary exhibition catalogs on which one should concentrate is that group of academy exhibitions produced in Europe since the eighteenth century. The Royal Academy in London from its establishment in 1768 produced a printed list of the exhibitors and names of pictures appearing in the annual spring exhibition. The French Academy did the same thing and also the British Institution in England. Although difficult to obtain, these catalogs of the national institution exhibitions are of basic importance for research in any of the European and American fields. Since they did not generally have illustrations, these can be obtained on microfilm, which would serve. This basic grouping would act as a classical collection. On this strong base one should attempt to add past and current catalogs.

Another kind of book which falls into neither of the above categories is the sales catalog. Only recently have American art reference libraries generally begun to build their collection of sales catalogs in the systematic way that it has been done abroad. Even now American libraries are far behind libraries in London and Paris in their sales cata$\log$ collections. Yet this is an area of great importance. Early sales catalogs are particularly rare and also very difficult to obtain. They are necessary in order to trace the provenance or history of a picture through the eighteenth and nineteenth centuries. Most often these early sales catalogs are without reproductions and can be easily microfilmed. Outstanding art reference libraries should have as complete microfilms of every 
sales catalog as possible. These could be obtained from such institutions as the Courtauld Institute in London where there is a large deposit of sales catalogs on hand with an accompanying highly useful index. Other sources can be found in Fritz Lugt's repertoire of sales catalogs which is the best listing.

The cataloging of sales catalogs is a technical problem in itself. Perhaps the most useful is that in the Victoria and $\mathrm{Al}$ bert Museum where there is a cross reference by auction house, filed by date. A complete index would list all artists, etc., but this is a virtually impossible task.

The Archives of American Art is undertaking the microfilming of all American sales catalogs, with cross-indexes. These will be of use in tracing European and American works of art.

The periodical collection is second in importance only to the collection of monographs. Today, periodicals are the record of our most advanced knowledge in the scientific fields and the same is true in the art history field. Periodicals are actually needed because the most recent information and all of the recent announcements and reviews of exhibitions are published in them. Just as with sales catalogs, the early periodicals no longer published have become standard reference works. Often these are enormously expensive and very difficult to purchase. The early numbers of the Gazette des beaux-arts, the Jahrbuch der preussischen Kunstsammlungen, or the Römisches Jahrbuch für Kunstgeschichte, the Art Union and Art Journal for England in the nineteenth century, the Kunst-Blatt for Germany, Rassegne darte and Rivista darte for Italy, are classical reference works. The usefulness and whereabouts of contemporary periodicals is not quite as difficult to know. The Art Bulletin, the Connoisseur, the Burlington Magazine are familiar to everyone. Even more specialized publications such as Master Drawings and the difficult Italian pe- riodicals, Proporzioni, Paragone, Arte Lombarda, and Arte veneta are widely known. The task is more intricate with Italian than with English periodicals, most of which are listed in Art Index. Keeping track of and indexing the innumerable Italian periodicals is a major task in itself.

Bulletins of museums pose their own problems and are indispensable to the art historian, but even more difficult to keep track of are the periodical publications of provincial intellectual societies such as the Servicio de Estudios Artisticos of the Institución Alfonso el Magnanimo which publishes the Disputación provincial de Valencia, or the Acts of the Archivio storico per le provincie parmensi; the latter frequently has art historical articles on artists who lived or worked in the Emilia. Another of this sort is the Annals of the government and city library of Cremona. These last two periodicals are being published today, and both of them frequently have articles by such outstanding scholars as Philip Pouncey on artists working in North Italy.

In the two cases just mentioned, the periodicals also contain literary, archaeological, social, and economic studies of local interest. Therefore, they must almost inevitably be part of a larger library complex rather than belonging only to the art reference library. In a situation where there is a university or a large public library in conjunction with the art research library, it is possible to have the larger library undertake such a project, which is too broadly based for the more special interests of the art library. Obviously, the best art reference library must exist in conjunction with a superb humanities library; only then can it be at its best.

With the tremendous number of art books published and offered on every side, the art librarian may often be confused as to just what kind of collection 
to stress, what kinds of books to buy. Currently-published monographs are an obvious thing to purchase; if they are the foundation of the collection, source books are its life blood. Source books are of numerous types, some of which have already been mentioned, and each has its own contribution to make to the art historian's arduous, unceasing quest to recreate the entire complex of the work of art and to trace it in its constant wanderings through time.

The first and most important source books are the treatises on painting, furniture, sculpture, etc., published from the sixteenth through the twentieth century. These constitute the original writings of artists themselves. Examples might include Alberti's treatise on painting, Leonardo's notebooks, Bellori's Idea, DuFresnoy's De Arte Graphica, Winckelmann's Nachahmungen, Sir Joshua Reynolds' Discourses, Fuseli's Lectures, David's Livret on the Sabines, Van Gogh's Letters, etc. What the artist himself thought about his work is important in recreating its original ambient. The early treatises published in the sixteenth and seventeenth centuries are particularly important in telling how art was taught, what was thought about it, what part it played in the lives of those for whom it was created. Oftentimes these were issued in a number of editions each with different, highly useful information. Thus, the different editions must constantly be checked and each one of importance added to the collection.

The second sort of source material which should be mentioned in this context are the early guidebooks to collections or to cities. Occasionally these are devoted primarily to works of art, but often paintings, sculpture, and buildings are mentioned only in passing. Yet the mention of the arrangement of a group of pictures in an eighteenth-century palace may be the only occasion we have to know of its existence and arrangement in that collection. A subsidiary type of source book which generally is found in the liberal arts library is the diary or letter which describes works of art viewed during the travels of a literateur or sightseer.

The third category of source material of particular use to the art historian comprises writings about art and artists by those who lived in the same period. That is, lives of artists, discussions of their techniques, notes about their daily life, habits, their studios, their views on art, their friends, and their patrons. This is the sort of invaluable information which the art historian cannot recreate without the evidence of those on the spot.

To be a truly strong art reference library, these primary source materials, treatises on art, guidebooks, and writings of the period about artists should be greatly in evidence. The book which provides the best commentary and the finest listing of these source books is Julius Schlosser's Die Kunstliteratur, which should be on every art librarian's desk and used as a kind of bible for building the collection.

The art librarian would seem to have much more to be aware of, to know, and to be sensitive to than most librarians. Not only must he be highly perceptive visually in order adequately to select slides and visual materials, but he must also actually be a kind of art historian. $\mathrm{He}$ must know which monuments and periods are most important. In other words, when there is a choice between two books on nineteenth-century ceramics or contemporary puppets and an eighteenthcentury treatise on painting or a catalog of Renaissance sculpture, the art librarian must know both instinctively and rationally which must be chosen. He must know what kinds of books are most important for the art historian's use. He must look through bibliographies in monographs and periodicals to make certain the library is up-to-date within 
its own collection. Naturally, this implies a complete and intimate acquaintance with the present collection of books.

When the art reference library is part of a museum, the art librarian has an especially demanding task. He must then have an intimate acquaintance with the existing museum collection. The library should be built in relation to that collection. Bibliographies should be constantly checked to make certain that the library has complete reference works on the collection as it now exists.

Unfortunately, the library cannot stop with the present collection. Works of art are constantly being offered to or purchased by the museum, and the librarian must anticipate by being aware of the gaps in the collection. For example, one knows that an important collection should have a Delacroix or an Ingres or a Manet. The librarian must say-someday we shall have a Manet, so we should purchase this minor work on Manet. Obviously, a major work on any artist would come to the library almost as a matter of course.

Thus the librarian must work closely with each of the curators. He must know what is being added to the museum collection and also what direction it is intended the collection will take. In this connection, he should constantly consult with the curator about additions to the library. The librarian should also know the curator's special interests, the areas in which he has published, and should add to the library with these interests in mind.

The physical appearance and arrangement of an art reference library should also have a special rationale. The card file should be readily available. There should be plenty of light in the reading room and in the stacks. The library should be quiet and conducive to study. It should be clean. The tables should be cleared of books, plants, etc. Only objects necessary for study should be on the library tables. Books not yet cataloged, etc., should be in adjoining rooms rather than in the main reading room. If this is impossible to attain, a section of the main reading room should be reserved for clerical and secretarial staff. There should be throughout an attitude which helps students in their work rather than distracting them from it. An attitude conducive to study and to the production of fine scholarship should pervade the entire library. In this respect, the library itself must be a kind of model. It must set standards which reach those of the carefully prepared studies which stand on its shelves.

An art reference library in particular should be visually splendid. Works of art, originals if possible, should be viewable in exquisite surroundings where scholars are inspired to pursue their studies by the standard of quality established by these rare objects. For, like them, a library is an idea. A library is a vision. It is more than a fantastically megalomaniacal grouping of pieces of rag and paper, a plethora of flipping leaves, a compound of print. A library is an extraordinary expression of a uniquely human capacity, the transferral of acquired experience and knowledge about it through words, pictures, diagrams, and formulas. It is the most vital of civilized institutions. It is without any doubt the most useful human tool.

Without a great library we are cut off from the fountainheads of our culture, without it we are behind the times, provincial, a noncreative and a noncontributing part of the society. Without this fundament of ideas and information, the society forges ahead and we fall behind. It is the vital link between us and civilization-a fundament from which we take and to which we contribute. It is the rich deep vein of our intellectual and emotional life from which we take life and return life to it. 